\title{
Prevalence and Predictive Factors of Urinary Retention Assessed by Ultrasound in the Immediate Post-anesthetic Period
}

\author{
Adilson José Dal Mago, TSA 1, Pablo Escovedo Helayel, TSA 22, Eduardo Bianchini ${ }^{3}$, Henrique Kozuki ${ }^{3}$, \\ Getúlio Rodrigues de Oliveira Filho, TSA 4
}

\begin{abstract}
Summary: Dal Mago AJ, Helayel PE, Bianchini E, Kozuki H, Oliveira Filho GR - Prevalence and Predictive Factors of Urinary Retention Assessed by Ultrasound in the Immediate Post-anesthetic Period.

Background and objectives: Urinary retention is a common condition in the post-anesthetic care unit (PACU). Vesical overdistension and consequent damage of the detrusor muscle of the urinary bladder represent situations that can be prevented. The ultrasound allows the reliable measurement of the urinary volume, determining the prevalence of postoperative vesical distension. The objective of the present study was to determine the prevalence of postoperative urinary retention and identify independent predictive factors.
\end{abstract}

Methods: Two-hundred and fifty-seven patients admitted to the PACU were included prospectively in this study. Parameters collected included: age, gender, physical status, site of surgery, type of anesthesia, time of the surgery and anesthesia, use of opioids, volume of fluids administered, and history of urinary symptoms. Vesical volumes were measured by ultrasound after admission and upon discharge from the PACU. The criteria to characterize urinary retention were: vesical volume equal or higher than $600 \mathrm{~mL}$ associated with incapacity of spontaneous micturition for 30 minutes after the diagnosis. Univariate and multivariate analyses were used to indentify independent predictive factors.

Results: Urinary retention was observed in 19 patients (7.39\%), independent predictive factors identified included urinary volume equal to or greater than $360 \mathrm{~mL}$ upon admission to the PACU (Mantel-Haenszel Chi-square test $(1 \mathrm{dF})=18.76 ; p<0.01$ ), with an odds ratio of 9.82 (95\% confidence interval $=3.26-29.55$ ) and surgeries of the lower limbs (Mantel-Haenszel Chi-square test $(1 \mathrm{dF})=5.33 ; p=0.02$ ), with odds ratio of $4.33(95 \%$ confidence interval $=1.34-14.02)$.

Conclusions: Due to the prevalence of urinary retention, we suggest that a systematic evaluation of the urinary volume at the PACU should be done, especially in those patients with predictive factors.

Keywords: COMPLICATIONS: urinary retention; EQUIPMENT: ultrasound; POST-ANESTHETIC RECOVERY.

[Rev Bras Anestesiol 2010;60(4): 383-390] CEIsevier Editora Ltda.

\section{INTRODUCTION}

Urinary retention is a common post-anesthetic complication associated with painful vesical distention and the risk of permanent damage of the detrusor muscle, and it might culminate on motility and atony problems especially in patients with advanced age ${ }^{1}$. Cardiovascular reactions such as bradycardia, asystole, hypertension, tachycardia, and arrhythmias can result from the activation of the autonomous nervous system related to vesical distension ${ }^{2}$.

In the past, the diagnostic hypothesis of urinary retention in the immediate post-anesthetic period was suspected due

Received from Hospital Governador Celso Ramos - CET/SBA aggregated of Secretaria de Estado da Saúde de Santa Catarina - Florianópolis - SC

1. Anesthesiologist; Co-responsible Instructor of the CET/SBA aggregated of SES-SC

2. Anesthesiologist; Co-responsible Instructor of CET/SBA; Coordinator of the Nucleus of Teaching and Research in Regional Anesthesia (NEPAR, from the Portuguese) of CET/SBA aggregated of SES-SC

3. Anesthesiology Resident

4. Anesthesiologist; Responsible for the CET/SBA aggregated of SES-SC

Submitted on February 10, 2010

Approved on April 5, 2010

Correspondence to:

Dr. Adilson José Dal Mago

Rua Trento, 130

88034-585 - Florianópolis, SC

E-mail: adalmago@ hotmal.com to symptoms and clinical signs such as pain, agitation, tachycardia, hypertension and by palpating the distended bladder, and the diagnosis was confirmed by vesical catheterization. Currently, ultrasound allows a fast diagnosis and it is a reliable, non-invasive, painless method with good reproducibility, which allows the precise and early diagnosis of the urinary volume, therefore avoiding excessive bladder distension ${ }^{3}$.

Postoperative urinary distension is defined as the incapacity to empty out a urine volume greater than $600 \mathrm{~mL}$ in 30 minutes after the diagnosis ${ }^{1}$. Prior studies identified several risk factors for the development of post-anesthetic urinary retention: anorectal surgeries, inguinal herniorrhaphies, history of urinary retention, neuroaxis block, anticholinergic medications, opioids, advanced age, and excess of fluids administered in the perioperative period ${ }^{1,3-5}$.

The objective of this study was to determine the prevalence of postoperative urinary retention and identify independent predictive risk factors.

\section{METHODS}

After approval by the Ethics on Research Committee of the Hospital Governador Celso Ramos and signing of the informed consent, 257 patients, ages between 15 and 96 years of 
both genders, scheduled for elective surgeries were enrolled in this study. Exclusion criteria were urgent surgeries and perioperative vesical catheterization.

The anesthetic technique was the choice of the anesthesiologist responsible for the patient.

Each patient was evaluated at the time of admission and discharge from the post-anesthetic care unit (PACU). The following parameters were collected: age, gender, physical status (ASA), presence of urinary symptoms in the pre-anesthetic history, site of the surgery, duration of the surgery, duration of anesthesia, use of opioids, urinary volume upon admission to the PACU (measured by US), urinary volume upon discharge from the PACU (measured by US), and volume of fluids administered during the transoperative period.

To measure the urine volumes on admission and upon discharge from the PACU an ultrasound equipment with a convex transducer of 2-5 MHz (Sonoace 8000 SE, Medison, South Korea) was used. Measurements were done with patients in dorsal decubitus. The transducer was placed on the suprapubic region in the transversal and longitudinal direction to determine the transverse, anteroposterior, and supero-inferior diameters of the bladder (Figure 1). The urinary volume was calculated automatically by the ultrasound equipment.

If a urine volume greater than $600 \mathrm{~mL}$ was identified the patient remained in the PACU and he/she was stimulated to urinate, guaranteeing a calm and isolated environment for 30 minutes. In case spontaneous micturition was not present, the patient underwent vesical catheterization and was considered as having post-anesthetic urinary retention.

For the statistical analysis the presence or absence of urinary retention according to the criteria established was considered the dependent variable. Based on this parameter, patients were divided in groups for univariate and multivariate analyses according to what is described below.

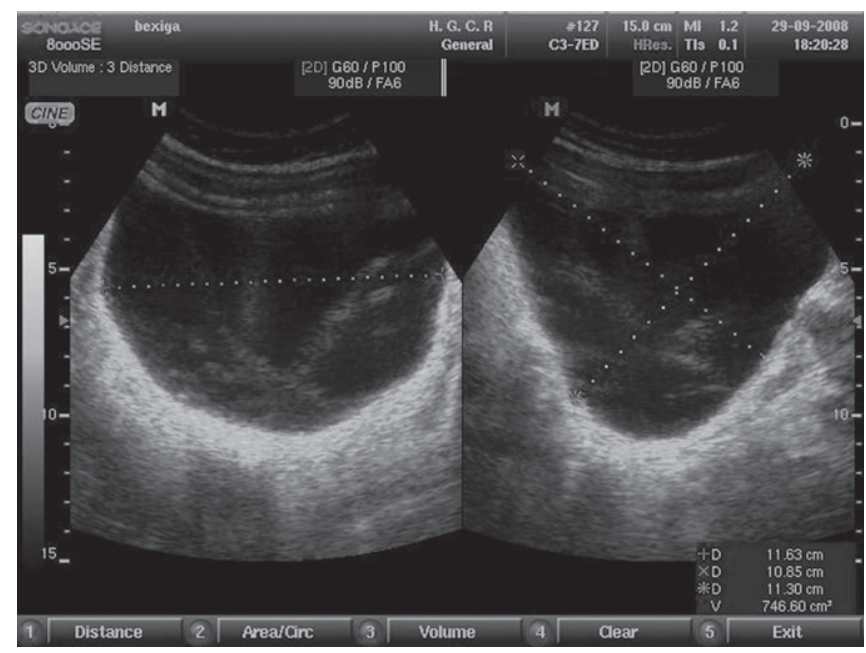

Figure-1 - Ultrasound Images of the Urinary bladder in Two Views. On the left, an image obtained with the transducer aligned to the transversal plane of the bladder. The dotted line represents the greater transversal diameter. The image on the right was obtained with the transducer aligned to the longitudinal axis of the bladder. The dotted lines represent the anteroposterior and supero-inferior diameters of the bladder.
Univariate analyses constituted of the Chi-square test for categorical parameters, and Student $t$ test for continuous variables were used to compare the groups of patients who developed and those that did not develop urinary retention.

A curve of the characteristics of the receptor and operator (ROC curve) was plotted for variables containing the volume of urine upon admission to the PACU in order to determine the presence of a volume that would be a cutting point to be included as a predictive parameter of urinary retention.

The Fisher exact test was used to identify significant differences in contingency tables greater than $2 \times 2$, in which the Chisquare test showed significant dependency between cells.

Parameters that differed between the groups underwent the Cochran and Mantel-Haenszel association dependency tests. The level of statistical significance was established at $5 \%$.

\section{RESULTS}

Table I shows the demographic data of the study sample.

Thirty-seven patients (14.39\%) presented urine volumes higher than $600 \mathrm{~mL}$ upon admission to the post-anesthetic

Table I - Demographic Data of the Study Population

\begin{tabular}{ll}
\hline Continuous parameters & Population \\
\hline Age (years) & $44.28(15-96)$ \\
Duration of the surgery (min) * & $75(5-225)$ \\
Duration of the anesthesia (min) * & $109(15-470)$ \\
Gender\# & \\
Male & $142(55)$ \\
Female & $115(45)$ \\
Physical status\# & \\
ASA I & $105(40.87)$ \\
ASA II & $135(52.53)$ \\
ASA III & $16(6.22)$ \\
ASA IV & $1(0.003)$ \\
Site of surgery & \\
Head and neck & $49(19.06)$ \\
Thorax & $3(1.16)$ \\
Abdomen & $35(13.61)$ \\
Upper limb & $39(15.17)$ \\
Lower limb & $114(44.35)$ \\
Perineum/genitals & $17(6.61)$ \\
Type of anesthesia $\#$ & \\
General & $89(34.63)$ \\
Neuroaxis & $91(35.4)$ \\
General + neuroaxis & $3(1.16)$ \\
Peripheral block & $57(22.17)$ \\
General + peripheral block & $17(6.61)$ \\
Opioids\# & \\
Intravenous & $176(68.48)$ \\
Intrathecal & $2(0.77)$ \\
No & $78(30.35)$ \\
Urinary symptoms & \\
Yes & $14(5.44)$ \\
No & $243(94.56)$ \\
\hline
\end{tabular}

*Parameters presented as mean and extremes;

\#Parameters presented as frequency in the sample and percentages. 
care unit. Out of those, 19 patients ( $7.39 \%$ of the total sample) were not able to urinate spontaneously within 30 minutes, and it was considered that they had developed post-anesthetic urinary retention.

Tables II and III shows the results of the univariate analyses. Significant differences were observed between patients who developed urinary retention and those who did not in univariate analyses of the following parameters: urinary volume upon admission in the PACU and surgeries of the lower limbs.

In multivariate analyses, both parameters were considered independent predictive factors. The urine volume equal to or higher than $360 \mathrm{~mL}$ upon admission to the PACU showed an odds ratio of 9.82 (95\% confidence interval $=3.26-29.55)$ (Mantel-Haenszel Chi-square test $(1 \mathrm{dF})=18.76$; $p<0.01$ ). Surgeries of the lower limbs were also independent predictive factors, with odds-ratio of 4.33 (95\% confidence interval = 1.34-14.02) (Mantel-Haenszel Chi-square test $(1 \mathrm{dF})=5.33$; $\mathrm{p}=0.02)$.

\section{DISCUSSION}

The prevalence of urinary retention ranges from $5 \%$ to $52 \%$ 1,3-5. This variation could be explained by the different criteria adop-

Table II - Comparison of Continuous Parameters Between Patients Who Developed and those Who did not Develop Urinary Retention

\begin{tabular}{llll}
\hline & Without retention & With retention & $\mathrm{p}$ \\
\hline Age & $44.29 \pm 18.63$ & $44.21 \pm 15.67$ & 0.99 \\
Duration of the surgery & $80.38 \pm 43.18$ & $76.32 \pm 47.55$ & 0.70 \\
Duration of the anesthesia & $119.37 \pm 62.75$ & $110.26 \pm 61.83$ & 0.54 \\
Urine volume upon admission to the PACU & $247.03 \pm 159.02$ & $540.58 \pm 237.66$ & 0.00 \\
Urine volume upon discharge from the PACU & $351.69 \pm 184.91$ & $779.11 \pm 166.69$ & 0.00 \\
Transoperative fluids & $1342.44 \pm 544.79$ & $1289.47 \pm 480.62$ & 0.68 \\
\hline
\end{tabular}

Parameters expressed as Mean \pm SD.

Table III - Comparison of Categorical Parameters between Patients Who Developed Urinary Retention and those Who did not

\begin{tabular}{|c|c|c|c|}
\hline & Without retention & With retention & $\chi^{2}$ \\
\hline Gender & & & $(1 \mathrm{dF})=0.23 ; p=0.63$ \\
\hline Male & $12(63)$ & $130(53)$ & \\
\hline Female & $7(37)$ & $108(45)$ & \\
\hline ASA I & $9(47)$ & $96(40)$ & \\
\hline ASA II & $9(47)$ & $126(53)$ & \\
\hline ASA III & $1(5)$ & $15(6)$ & \\
\hline Head and Neck & $3(16)$ & $46(19)$ & \\
\hline Thorax & $0(0)$ & $3(1)$ & \\
\hline Abdomen & $0(0)$ & $35(15)$ & \\
\hline Upper limbs & $1(5)$ & $38(16)$ & \\
\hline Lower limbs & $15(79)$ & $99(42)$ & \\
\hline General + Neuroaxis & $0(0)$ & $3(1)$ & \\
\hline Peripheral block & $2(11)$ & $55(23)$ & \\
\hline General + Peripheral block & $2(11)$ & $15(6)$ & \\
\hline Opioid use & & & $(1 \mathrm{dF})=0.019 ; p=0.89$ \\
\hline No & $5(26)$ & $73(31)$ & \\
\hline Yes & $14(74)$ & $165(69)$ & \\
\hline Urinary symptoms & & & $(1 \mathrm{dF})=0.3 ; p=0.62$ \\
\hline No & $18(95)$ & $225(95)$ & \\
\hline Yes & $1(5)$ & $13(5)$ & \\
\hline Urine volume upon admission to the PACU & & & $(1 \mathrm{dF})=20.89 ; p<0.01$ \\
\hline$<360 \mathrm{~mL}$ & $5(29)$ & $192(81)$ & \\
\hline$>360 \mathrm{~mL}$ & $12(71)$ & $46(19)$ & \\
\hline
\end{tabular}

Results presented as frequency and percentage

$\chi^{2}=$ Chi-square; $\mathrm{dF}=$ degrees of freedom. 
ted in the different studies to define urinary retention. Another relevant factor is the difference in the diagnostic methods used. In prior studies, predictive factors for urinary retention were age, gender, physical status, type of anesthesia, history of urinary symptoms, amount of fluids administered, inguinal herniorrhaphies, and anorectal surgeries. The present study adds to those criteria surgeries of the lower limbs and urinary volume equal to or higher than $360 \mathrm{~mL}$ upon admission to the PACU as independent predictive factors for urinary retention.

The study has limitations imposed by the sampling method. In our cohort, the surgical procedures did not have a homogenous representation. For example, anorectal surgeries represented only $7 \%$ of the sample while surgeries of the lower limbs represented $45 \%$. The period of evaluation of the patients was restricted to the immediate postoperative period (period of staying in the PACU). In a study in which patients were followed-up for the 24 postoperative hours, $25 \%$ of the patients developed urinary retention increasing the incidence of $5 \%$ originally observed ${ }^{4}$. A standardization regarding the volume of perioperative fluids was not used in this study, which made it impossible to stratify the sample according to this parameter unlike another study which identified the volume of fluids administered as a risk factor ${ }^{1}$.

The use of the ultrasound as an evaluation and monitoring instrument of the urine volume showed to be a very reliable method. According to Keita et al. ${ }^{1}$, it has a sensitivity of $97 \%$, specificity of $91 \%$, and accuracy of $94 \%$ in the identification of urine volumes greater than or equal to $100 \mathrm{~mL}$. Pavlin et al. 4,5 observed a difference of only $15 \mathrm{~mL}$ between the urine volume estimated by ultrasound and the volumes drained by vesical catheterization.

The low sensitivity of the palpation method on the diagnosis of a vesical globe and the presence of urinary retention without pain in up to $61 \%$ of the cases are easily overcome by ultrasound 4,5 . The relevance of the early identification of vesical distention resides in the fact that prolonged distension of the bladder can cause damage of the detrusor muscle and vesical dysfunction.

We conclude that urine retention in the immediate postoperative period observed in $7.39 \%$ of the patients in the present study was associated with two independent predictive factors: surgeries of the lower limbs and vesical volume equal to or higher than $360 \mathrm{~mL}$ upon admission to the PACU. Considering the clinical repercussions that non-diagnosed urine retention can cause, and the advantages that the ultrasound has to this end, we suggest that the systematic evaluation of the vesical contents of patients at the time of admission to the PACU should be done especially in those patients who have any risk factor. 


\section{REFERÊNCIAS / REFERENCES}

01. Keita H, Diouf E, Tubach F et al. - Predictive factors of early postoperative urinary retention in the postanesthesia care unit. Anesth Analg, 2005;101:592-596.

02. Oliveira Filho GR - Rotinas de cuidados pós-anestésicos de anestesiologistas brasileiros. Rev Bras Anestesiol, 2003;53:518-534.

03. Rosseland LA, Stubhaug A, Breivik H - Detecting postoperative urinary retention with an ultrasound scanner. Acta Anaesthesiol Scand, 2002;46:279-282.

04. Pavlin DJ, Pavlin EG, Fitzgibbon DR et al. - Management of bladder function after outpatient surgery. Anesthesiology, 1999;91:42-50.

05. Pavlin DJ, Pavlin EG, Gunn HC et al. - Voiding in patients managed with or without ultrasound monitoring of bladder volume after outpatient surgery. Anesth Analg, 1999;89:90-97.

Resumen: Dal Mago AJ, Helayel PE, Bianchini E, Kozuki H, Oliveira Filho GR - Prevalencia y Factores Predictivos de Retención Urinaria Diagnosticada por Ultrasonido en el Período Postanestésico Inmediato.

Justificativa y objetivos: La retención urinaria es una condición frecuente en la sala de recuperación postanestésica (SRPA). La sobredistensión vesical y la consecuente lesión del detrusor de la vejiga son situaciones que se pueden prevenir. El ultrasonido permite una medida confiable del volumen urinario, determinando la prevalencia de la distensión vesical postoperatoria. Este estudio tuvo el objetivo de determinar la prevalencia de retención urinaria postoperatoria e identificar los factores independientes de previsión para su aparecimiento.

Método: Doscientos cincuenta y siete pacientes admitidos en la SRPA fueron prospectivamente incluidos en el estudio. Las variables recolectadas incluyeron: edad, sexo, estado físico, local de la cirugía, tipo de anestesia, tiempos quirúrgico y anestésico, uso o no de opioides, volumen de fluidos administrados, e historial previo de síntomas urinarios. Las medidas del volumen vesical fueron realizadas por ultrasonido, en la entrada y en el alta de la SRPA. El criterio para caracterizar la retención urinaria fue el volumen vesical igual o mayor que $600 \mathrm{~mL}$, asociado a la incapacidad de micción espontánea 30 minutos después del diagnóstico. Los análisis univariados y multivariados fueron utilizados para identificar los factores predictivos independientes.

Resultados: Ocurrió una retención urinaria en 19 pacientes (7,39\%). Los factores predictivos independientes identificados fueron el volumen urinario igual o mayor que $360 \mathrm{~mL}$ en la admisión a la SRPA (Cui-cuadrado de Mantel-Haenszel (1 gl.) = 18,76; $p<0,01$ ), con razón de chances de 9,82 (intervalo de $95 \%$ de confianza $=3,26-$ $29,55)$ y las cirugías sobre los miembros inferiores (Cui-cuadrado de Mantel-Haenszel ( $1 \mathrm{gl}$.) $=5,33 ; p=0,02$ ), con razón de chances de 4,33 (intervalo de un $95 \%$ de confianza $=1,34-14,02$ ).

Conclusiones: dada la prevalencia de la retención urinaria, se sugiere una evaluación sistemática del volumen urinario en la SRPA, particularmente en los pacientes portadores de factores predictivos. 